\title{
Nucleotide Sequence of an OXA-2 $\beta$-Lactamase Gene from the R-Plasmid R1767 Derived Plasmid pBP11 and Comparison to Closely Related Resistance Determinants Found in R46 and Tn2603
}

\author{
By E. J. NÜCKEN, R. B. HENSCHKE AND F. R. J. SCHMIDT* \\ Institut für Bodenbiologie, Bundesforschungsanstalt für Landwirtschaft, Bundesallee 50, \\ 3300 Braunschweig, FRG
}

(Received 21 June 1988; revised 23 November 1988; accepted 8 December 1988)

\begin{abstract}
Plasmid pBP11 contains a sequence homologous to Tn2l-like element Tn2410 encoding dihydropteroate synthetase and $\beta$-lactamase OXA-2. The nucleotide sequence of a $1.5 \mathrm{~kb}$ segment of this region has been determined including the bla gene. It reveals strong sequence homology with the OXA-2 operon of plasmid R46. The implications of an additional $319 \mathrm{bp}$ segment in pBP11 for the different evolution of R46/pKM101 and pBP11 are discussed.
\end{abstract}

\section{INTRODUCTION}

Resistance to ampicillin, penicillin and other $\beta$-lactam antibiotics can be mediated by different enzymes. The majority of these $\beta$-lactamases are encoded by plasmids (Foster, 1983), some of which carry the bla genes on transposable elements, favouring their dissemination in bacterial hosts. Some of the different $\beta$-lactamase genes are well characterized. Ouellette $e t$ al. (1987) have sequenced the OXA-1 $\beta$-lactamase gene (oxal) from Tn2603, an element closely related to Tn2l (Tanaka et al., 1983). Furthermore, Dale et al. (1985) and Hall \& Vockler (1987) have determined the DNA sequence of the OXA-2 $\beta$-lactamase (oxa2) expressed by resistance plasmid R46, originally found in Salmonella typhimurium (Anderson \& Datta, 1965). In this replicon the bla gene is located adjacent to aadA $\left(\mathrm{Sm}^{\mathrm{r}} / \mathrm{Sp}^{\mathrm{r}}\right)$ and $s u l\left(\mathrm{Su}^{\mathrm{r}}\right)$, a segment revealing strong homology to $\mathrm{Tn} 2 l$ and related transposons in its restriction patterns and sequence (Hall \& Vockler, 1987). Plasmid pKMl01 is a deletion derivative of R46 which has lost the $\mathrm{Su}^{r}$ and $\mathrm{Sm}^{r} / \mathrm{Sp}^{r}$ determinants (Hall \& Vockler, 1987).

The conjugative R plasmid R1767 was also derived from a clinical isolate of $S$. typhimurium (Richmond \& Wiedemann, 1974). It too mediates resistance to ampicillin by an OXA-2 $\beta$ lactamase. A derivative of this plasmid is pBP11 ( $\mathrm{Tra}^{-}$) (Schmidt et al., 1982), a $26.4 \mathrm{~kb}$ replicon harbouring its oxa 2 and sul resistance determinants on a $6.8 \mathrm{~kb}$ duplication. The central region of pBP11 comprising sul, oxa and res is totally homologous to the corresponding part of $\operatorname{Tn} 2410$ (Kratz et al., 1983a,b). In this paper the nucleotide sequence of its OXA-2 $\beta$-lactamase gene and flanking regions are presented. The relationship of the gene and its sequence organization to other oxa determinants of R46, Tn2603 and to $\mathrm{Tn} 21$ is discussed.

\section{METHODS}

Bacterial strains and plasmids. Escherichia coli strain RRIDM15 (Rüther, 1982) was used as a host for plasmids. Plasmid pUC19 (Norrander $\mathrm{et}$ al., 1984) served as a vector for cloning DNA fragments and mediated resistance to ampicillin. Plasmid pBP11 (Schmidt et al., 1982) served as source for the OXA-2 gene from R1767.

Culture conditions. Growth media and testing for antibiotic sensitivity were as described by van Treeck et al. (1981).

DNA techniques. Preparation of plasmid DNA, restriction analysis, molecular cloning and transformation of DNA was done as described previously (Schmidt et al., 1982). 
Nucleotide sequence determination. DNA sequencing was done by the method of Maxam \& Gilbert (1977) with some modifications as given by Rüther (1982). The 5'-ends of DNA fragments to be sequenced were labelled by treatment with alkaline phosphatase followed by incubation with polynucleotide kinase and $\left[\gamma-{ }^{32}\right.$ P]ATP (Maxam $\&$ Gilbert, 1977). The $3^{\prime}$-ends were labelled by filling in 5 '-protruding ends using Klenow fragment of $E$. coli DNA polymerase I and appropriately labelled $\left[\alpha-{ }^{32}\right.$ P]dNTPs (Maniatis et al., 1982). Prior to base specific sequencing reactions, labelled fragments were purified by preparative agarose gel $(1.4 \%)$ electrophoresis.

Computer analysis. The programs of Devereux \& Haeberli (UWGCG) from the University of Wisconsin (Devereux et al., 1984) were used to analyse DNA and amino acid sequence, to compare sequences for homologies and to search for transcriptional and translational signals.

\section{RESULTS AND DISCUSSION}

To determine the nucleotide sequence of the OXA-2 $\beta$-lactamase gene from R1767, a $2.8 \mathrm{~kb}$ HindIII/BamHI fragment containing the resistance gene from pBP1l (Schmidt et al., 1982) was cloned into pUC19. Using the restriction enzyme sites given in Fig. 1, smaller parts from this fragment were subcloned into the pUC vector before sequencing. In addition Bal31 deletions from the $2.8 \mathrm{~kb}$ fragment were generated, cloned into pUC19 and sequenced. Using all these clones we have determined the DNA sequence given in Fig. 1. The sequence comprises the region coding for OXA-2 $\beta$-lactamase and its flanking region.

The results of sequence comparisons to other bla genes are given in Fig. 2. The coding sequence of pBP11 (bases 221-1048) is totally homologous to the corresponding DNA sequences published by Dale et al. (1985) and Hall \& Vockler (1987), revealing that pBP11 contains a bla gene identical with that of plasmid R46. As given in Fig. 2, there is no significant homology to the DNA sequence of the OXA-1 $\beta$-lactamase published by Ouellette et al. (1987). Further DNA sequence homology was found concerning bases 1-201 and 1398-1519 given in Fig. 1. These parts of our sequence resemble the sequences flanking the aadA gene of $\operatorname{Tn} 21$ (Hollingshead \& Vapnek, 1985) (Fig. 2). The only difference between these two sequences is the presence of seven additional bases in the $\mathrm{Tn} 21$ region. The extra bases of $\mathrm{Tn} 21$ are given in Fig. 1 (inserts at position 65, 76 and 85). The DNA homology was expected because $\mathrm{Tn} 21$ is the presumed ancestor of the R1767-derived transposon Tn2410 (Kratz et al., 1983b). pBP11 represents the whole antibiotic-resistance region from $\mathrm{Tn} 2410$ (Kratz et al., 1983a). As can be seen in Fig. 2, some regions of the other presented structures also show a strong homology to the DNA sequence from $\mathrm{Tn} 21$. This is not surprising since R46 and $\mathrm{Tn} 2603$ are closely related to the Tn21 structure (Hall \& Vockler, 1987; Ouellette et al., 1987). Both R46 and Tn 2603 harbour a $\beta$ lactamase gene adjacent to aadA due to an insertion event whereas pBP11 is supposed to represent a substitution derivative of the Tn21 structure (Kratz et al., 1983 b). In all structures given in Fig. 2 the oxa genes are located on the $5^{\prime}$ end of aadA. The DNA sequences of these regions in Tn2603, R46, pKM101 and pBP11 show complete homology with the DNA sequence published by Hollingshead \& Vapnek (1985). In R46 and Tn2603 the homology with this sequence continues on the $3^{\prime}$ side of oxa 2 corresponding with the initiation signal sequence of aad $A$. However, pBP11 provides an altered sequence organization. It lacks the aad $A$ resistance gene. The homology with Tn21 continues at the $3^{\prime}$ end of aadA (from position 1398 in Fig. 1). From these sequence data it can be seen that pBP11 contains an OXA-2 gene totally substituting the aad $A$ coding region. However, the aadA substitution in pBP11 does not comprise only the OXA-2 gene but includes an additional DNA segment of 319 nucleotides. Searching for open reading frames in this region revealed only three very short polypeptides. The first one would use the start codon ATG at position 1109 and the stop codon TAG at position 1181 . The resulting polypeptide would consist of 24 amino acids. The next possible coding region uses the complementary strand and extends from base 1413 to base 1299 . This would result in a 30 amino acid polypeptide. The third protein could be encoded from the complementary strand of bases 1370 to 1247 and the polypeptide would be 41 amino acids long. All three proposed proteins would be very small. The amino acid sequences of these possible proteins showed no detectable homology with any of the protein sequences of the Protein Identification Resource (PIR) database from the National Biomedical Research Foundation. A comparison of the nucleotide sequence of the unique segment with the National Institutes of Health GenBank database 


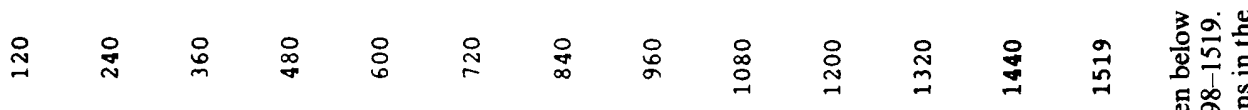

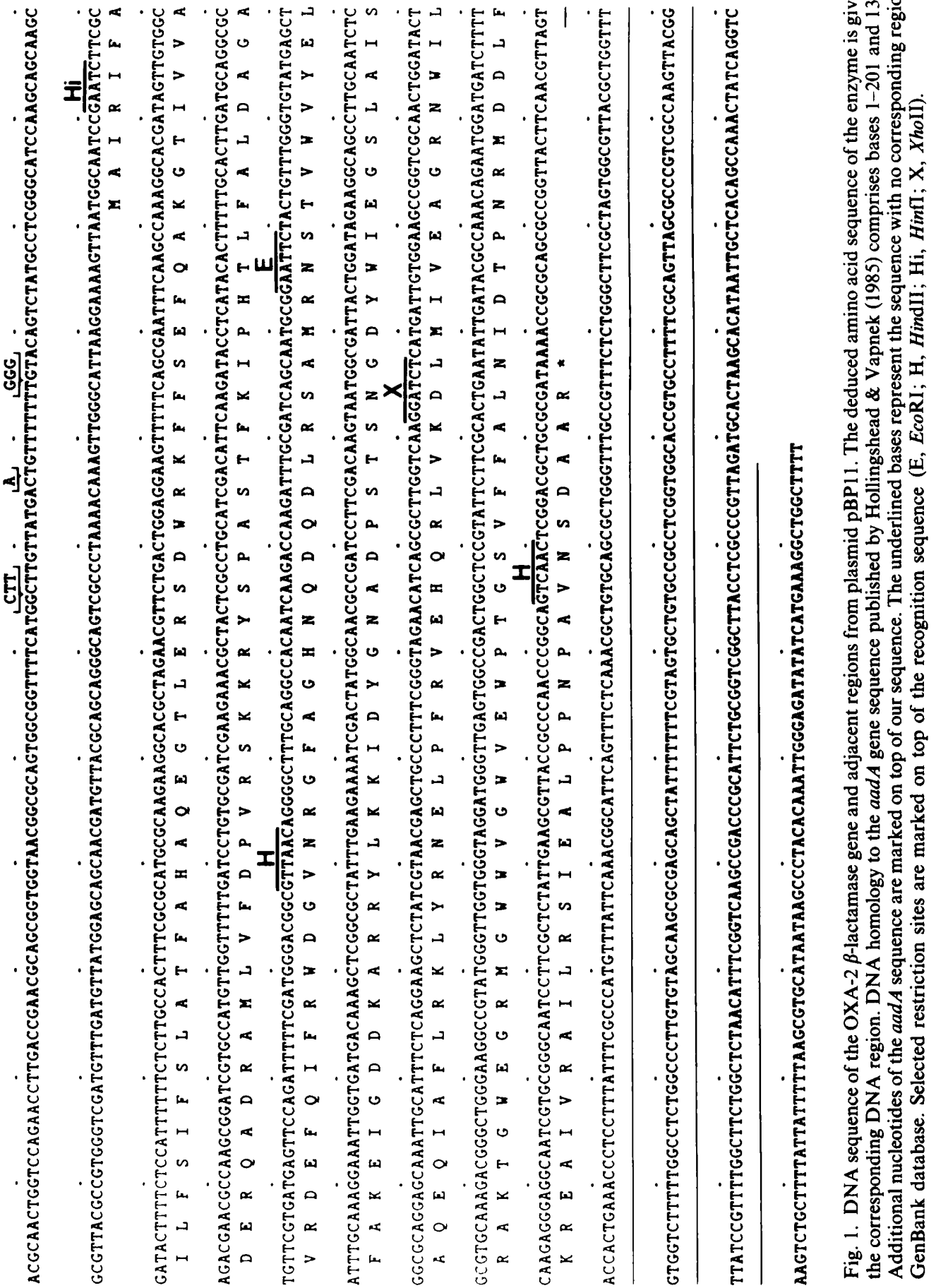




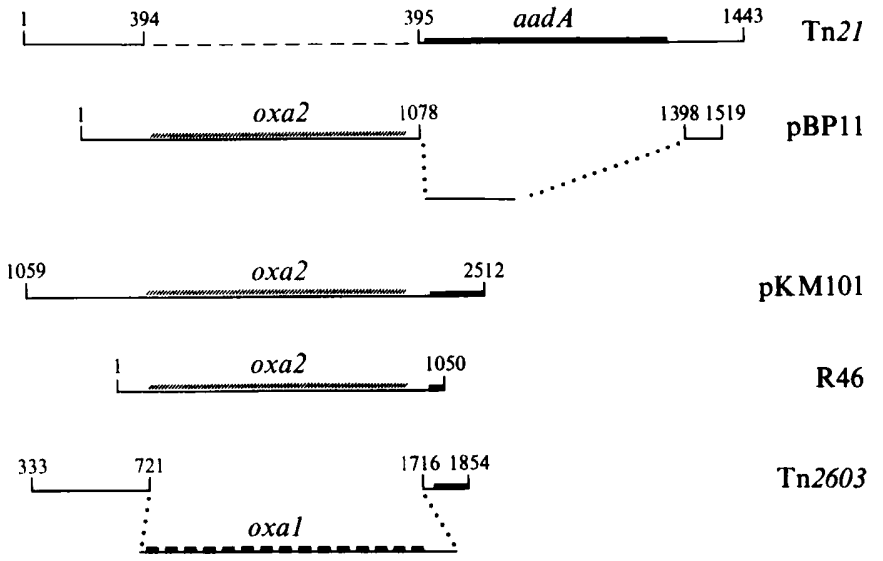

Fig. 2. Schematic presentation of the organization of selected $\beta$-lactamase-gene-harbouring structures. Tn2l is from Hollingshead \& Vapnek (1985), pKM101 from Hall \& Vockler (1987), R46 from Dale et al. (1985), and Tn2603 from Ouellette et al. (1987). The enumeration (small numbers) is the same as given in the corresponding publications. The broken line in $\mathrm{Tn} 21$ indicates the region of insertion/substitution. Coding regions are marked by bars; a black bar for aadA, a shaded bar for oxa 2 and a broken bar for oxal. Mere horizontal lines represent regions of homology with the $\mathrm{Tn} 21$ backbone, whereas regions flanked by dotted lines indicate unique sequences.

provided no significant homology with any of the sequences. Both the function and origin of this part of the plasmid pBP11 need further clarification. The presence of the additional $319 \mathrm{bp}$ segment at the $3^{\prime}$ end of oxa in pBP11 supposes an oxa 2 integration event in pBP11 and Tn2410 differing from that in plasmid R46. While plasmid R46 is considered to be a predecessor of pKM101 (Hall, 1987) no predecessor is known for pBP11. Both pBP11 and pKM101 are spectinomycin sensitive due to different deletion events. IS46 is responsible for the deletion in pKM101 (Hall, 1987) leaving parts of the N-terminus of aadA in pKM101 (Fig. 2). In pBP11 and $\operatorname{Tn} 2410$ the complete aadA gene is deleted. Thus it is most likely that pBP11 and $\operatorname{Tn} 2410$ have evolved from $\mathrm{Tn} 21$ by insertion of $o x a 2$ plus additional sequences (unique segment of $319 \mathrm{bp}$ ) followed by deletion of the aadA gene.

So far the presented data imply the parallel development of plasmids pBP11 and pKM101, providing an example of a convergent evolution.

This work was supported by a grant from the Deutsche Forschungsgemeinschaft to F. Schmidt.

\section{REFERENCES}

Anderson, E. S. \& DATTA, N. (1965). Resistance to penicillins and its transfer to Enterobacteriaceae. Lancet 1, 407-409.

Dale, J. W., Godwin, D., Mossakowska, D., Stephenson, P. \& Wall, S. (1985). Sequence of the OXAII $\beta$-lactamase: comparison with other penicillin reactive enzymes. FEBS Letters 191, 3944.

Devereux, J., Haeberli, P. \& Smithies, O. (1984). A comprehensive set of sequence analysis programs for the VAX. Nucleic Acids Research 12, 387395.

Foster, T. J. (1983). Plasmid-determined resistance to antimicrobial drugs and toxic metal ions in bacteria. Microbiological Reviews 47, 361-409.
HALL, R. M. (1987). pKM101 is an IS46-promoted deletion of R46. Nucleic Acids Research 15, 5479.

HALL, R. M. \& VoCKLER, C. (1987). The region of the IncN plasmid R46 coding for resistance to $\beta$-lactam antibiotics, streptomycin/spectinomycin and sulphonamides is closely related to antibiotic resistance segments found in IncW plasmids and in Tn21-like transposons. Nucleic Acids Research 15, 7491-7501.

Hollingshead, S. \& VAPNEK, D. (1985). Nucleotide sequence analysis of a gene encoding streptomycin/ spectinomycin adenyltransferase. Plasmid 13, 17-30.

Kratz, J., Schmidt, F. \& WiedemanN, B. (1983a). Transposition of a gene encoding OXA- $2 \beta$-Lactamase. Journal of General Microbiology 129, 29512957. 
Kratz, J., Schmidt, F. \& WiedemanN, B. $(1983 b)$ Characterization of $\mathrm{Tn} 2411$ and $\mathrm{Tn} 2410$, two transposons derived from R-plasmid R1767 and related to $\operatorname{Tn} 2603$ and $\operatorname{Tn} 21$. Journal of Bacteriology 155 , 1333-1342.

Maniatis, T., Fritsch, E. F. \& Sambrook, J. (1982). Molecular cloning : a Laboratory Manual. Cold Spring Harbor, NY: Cold Spring Harbor Laboratory.

MaXam, A. M. \& Gilbert, W. (1977). A new method for sequencing DNA. Proceedings of the National Academy of Sciences of the United States of America 74, 560-564.

Norrander, J., Kempe, T. \& Messing, J. (1984). Construction of improved M13 vectors using oligodeoxynucleotide-directed mutagenesis. Gene 26, 101-106.

OUELletTE, M., BissonNetTe, L. \& RoY, P. H. (1987) Precise insertion of antibiotic resistance determinants into Tn21-like transposons: nucleotide sequence of the OXA-I $\beta$-lactamase gene. Proceedings of the National Academy of Sciences of the United States of America 84, 7378-7382.
Richmond, M. H. \& WiedemanN, B. (1974). Plasmids and bacterial evolution. In Evolution in the Microbial World, pp. 59-85. London \& New York: Cambridge University Press.

RÜTHER, U. (1982). pUR250 allows rapid chemical sequencing of both DNA strands and its inserts. Nucleic Acids Research 10, 5765-5772.

SChmidt, F., van Treek, U. \& WiedemanN, B. (1982). Multimerization and replication of plasmid pBP11. Plasmid 8, 126-140.

Tanaka, M., Yamamoto, T. \& Sawai, T. (1983). Evolution of complex resistance transposons from an ancestral mercury transposon. Journal of Bacteriology 153, 1432-1438.

Van Treek, U., Schmidt, F. \& WiedemanN, W. (1981). Molecular nature of a streptomycin and sulphonamide resistance plasmid (pBP1) prevalent in clinical Escherichia coli strains and integration of an ampicillin resistance transposon $(\operatorname{Tn} A)$. Antimicrobial Agents and Chemotherapy 19, 371-380. 